\title{
SLC2A4 Gene
}

National Cancer Institute

\section{Source}

National Cancer Institute. SLC2A4 Gene. NCI Thesaurus. Code C89034.

This gene plays a role in glucose transport regulation. 